\begin{tabular}{|c|c|c|}
\hline Homepage: http://jusami.batan.go.id & Jurnal Sains Materi Indonesia & $\begin{array}{l}\text { Akreditasi LIPI } \\
\text { No.: 602/AU3/P2MI-LIPI/03/2015 } \\
\text { Tanggal 15 April 2015 } \\
\text { ISSN : 1411-1098 }\end{array}$ \\
\hline
\end{tabular}

\title{
EFEK ADITIF FeMo DAN PROSES KALSINASI PADA SERBUK MAGNETIK BaFe ${ }_{12} \mathrm{O}_{19}$
}

\author{
Ayu Yuswita Sari ${ }^{1}$, Cut Hani Safira ${ }^{2}$, Eko Arief Setiadi' ${ }^{1}$ Siviana Simbolon ${ }^{3}$, \\ Candra Kurniawan ${ }^{1,3}$ dan Perdamean Sebayang, \\ ${ }^{1}$ Pusat Penelitian Fisika - LIPI \\ Kawasan Puspiptek, Serpong 15314,Tangerang Selatan \\ ${ }^{2}$ Departemen Fisika, FMIPA, Universitas Sumatera Utara \\ Jl. Bioteknologi No. 1, Medan, Sumatera Utara \\ ${ }^{3}$ Program Studi Teknik Mesin, Universitas Pamulang \\ Jl. Surya Kencana No. 1, Tangerang Selatan \\ E-mail:ayuy001@lipi.go.id
}

Diterima: 23 Desember 2016

Diperbaiki: 21 Maret 2017

Disetujui: 3 April 2017

\begin{abstract}
ABSTRAK
EFEK ADITIF FeMo DAN PROSES KALSINASI PADA SERBUK MAGNETIK BaFe ${ }_{12} \mathrm{O}_{19}$. Pada penelitian ini, telah dilakukan investigasi efek aditif FeMo dan proses kalsinasi pada pembuatan magnet permanen barium heksaferit $\left(\mathrm{BaFe}_{12} \mathrm{O}_{19}\right)$. Proses pembuatan magnet barium heksaferit dilakukan dengan metode mechanical alloying. Serbuk hasil mixing antara $\mathrm{BaFe}_{12} \mathrm{O}_{19}$ dan $\mathrm{FeMo}$ dikalsinasi dengan variasi suhu kalsinasi $1000{ }^{\circ} \mathrm{C}$ dan $1200{ }^{\circ} \mathrm{C}$. Karakterisasi yang dilakukan meliputi sifat fisis dan magnetik, dengan menggunakan $X$-Ray Diffraction $(X R D)$ dan piknometeruntuk mengetahui fasa dan nilai densitas magnet, serta menggunakanVibrating Sample Magnetometer (VSM) pada pengukuran sifat magnetik magnet barium heksaferit. Dari hasil eksperimen, dapat diketahui bahwa penambahan aditif FeMo dapat menaikkan nilai densitas pada serbuk barium heksaferit. Hasil analisis sifat magnetik, dapat diketahui bahwa penambahan aditif FeMo secara keseluruhan menurunkan sifat magnetik magnet. Namun penambahan \%wt FeMo menaikkan nilai remanensi, saturasi dan energi produk maksimum $\left(\mathrm{BH}_{\max }\right)$ magnet barium heksaferit, meskipun nilai koersivitas magnet tetap menurun. Sedangkan kenaikan suhu kalsinasi mampu menaikkan nilai remanensi, dan $\mathrm{BH}_{\max }$, namun menurunkan nilai koersivitas dan saturasi dari magnet barium heksaferit. Hal ini menunjukkan penambahan zat aditif FeMo mampu mengubah struktur material magnet permanen barium heksaferit dari hard magnetik menjadi soft magnetik material. Nilai optimum dihasilkan pada komposisi penambahan $5 \%$ wt aditif FeMo dengan nilai densitas serbuk $3,71 \mathrm{~g} / \mathrm{cm}^{3}$ sebelum dikalsinasi, dan memiliki sifat magnetik seperti: saturasi 2,12 kG, remanensi 1,15 kG, koersivitas 0,45 kOe dan $\mathrm{BH}_{\max } 0,145$ MGOe setelah dikalsinasi pada suhu $1000^{\circ} \mathrm{C}$.
\end{abstract}

Kata kunci: $\mathrm{BaFe}_{12} \mathrm{O}_{19}$, FeMo, Mechanical Alloying, Kalsinasi, Vibrating Sample Magnetometer

\begin{abstract}
EFFECT OF FeMO ADDITIVE AND CALCINATION PROCESS ON MAGNETIC POWDERS $\mathbf{B a F e}_{12} \mathbf{O}_{19}$. In this study, we have been investigated the effect of FeMo additive and calcination process in magnet permanent barium hexaferrite. The permanent magnet of barium hexaferrite was prepared by mechanical alloying method. The mixing powder of $\mathrm{BaFe}_{12} \mathrm{O}_{19}$ and FeMo was calcinated on 1000 and $1200{ }^{\circ} \mathrm{C}$ prepared of temperature. The characterization was done for physical and magnetic properties with $X$-ray Powder Diffraction $(X R D)$ and piknometer for the phase of material and the powder density and then Vibrating Sample Magnetometer $(V S M)$ for the magnetic properties of barium hexaferrite magnet. The experiment result showed analysis that addition of FeMo increased the powder density of barium hexaferrite. The magnetic properties result showed that increasing of FeMo additive make deacreassing of magnetic characterization. While the more addition of FeMo can be increases remanence, saturation, and $\mathrm{BH}_{\max }$ Even though deacreases the coercivity. The increasing of calcination temperature can increases remanence and $\mathrm{BH}_{\max }$ but deacreases saturation and coercivity. It means
\end{abstract}


the process can changes the magnet structure from hard to soft magnetic material. The optimum value, when the barium hexaferrite add \%wt $5 \mathrm{FeMo}$ additive with $3.71 \mathrm{~g} / \mathrm{cm}^{3}$ powder density before calcination process. And the magnetic properties such as: saturation $2.12 \mathrm{kG}$, remanence $1,15 \mathrm{kG}$, coercivity $0,45 \mathrm{kOe}$ dan $\mathrm{BH}_{\max } 0,145$ MGOe after calcination process at $1000{ }^{\circ} \mathrm{C}$.

Keywords: $\mathrm{BaFe}_{12} \mathrm{O}_{19}$, FeMo, Mechanical Alloying, Calcination, Vibrating Sample Magnetometer

\section{PENDAHULUAN}

Barium heksaferit $\left(\mathrm{BaFe}_{12} \mathrm{O}_{19}\right)$ merupakan magnet permanen yang banyak digunakan karena bahannya melimpah dan harganya relatif murah [1-2]. Barium heksaferit memiliki nilai magnetik anisotropi dan suhu Curie yang tinggi dengan kestabilan kimia yang cukup baik [3]. Material tersebut memiliki koersivitas instrinsik 6700 Oe, magnetik saturasi $72 \mathrm{emu} / \mathrm{g}$, dan suhu Curie $450^{\circ} \mathrm{C}$. Barium heksaferit $\left(\mathrm{BaFe}_{12} \mathrm{O}_{19}\right)$ telah digunakan secara luas pada pembuatan magnet permanen komersial, penyimpanan data (hard discs),loudspeakers, microphones, magnetic separator, dan lainnya[4]. Teknik sintesis pada barium heksaferit $\left(\mathrm{BaFe}_{12} \mathrm{O}_{19}\right)$ dapat dibagi secara fisika dan kimia [5]. Teknik fisika yang biasa dilakukan adalah metode reaksi padatan (mechanical alloying). Selanjutnya, dilakukan proses kalsinasi untuk stabilitas fasa dan densifikasi dalam bentuk serbuk [6].

Pada proses mechanical alloying, distribusi serbuk yang homogen merupakan faktor penting yang mempengaruhi proses ferrization dan sifat magnetik ferit. Proses wet milling pada serbuk lebih dianjurkan karena dapat menghasilkan distribusi partikel yang lebih merata dari pada proses dry milling [7]. Pada serbuk $\mathrm{BaFe}_{12} \mathrm{O}_{19}$ diberikan penambahan aditif Ferro Molybdenum (FeMo) yang secara luas digunakan dalam produksi baja stainless tahan panas dan paduan baja lainnya. Molybdenum meningkatkan kekerasan ferit, dan bahkan lebih besar daripada austenit. Penambahan Ferro-Molybdenum dapat meningkatkan kekerasan komposit keramik secara signifikan [8]. Penambahan aditif FeMo pada serbuk $\mathrm{BaFe}_{12} \mathrm{O}_{19}$ diharapkan dapat menghasilkan soft magnetik dan dapat digunakan sebagai material absorber. Barium M-Heksaferit terbentuk paling tidak pada suhu $1000^{\circ} \mathrm{C}$ agar menjadi produk utama [9].

Penelitian mengenai penambahan aditif FeMo pada serbuk $\mathrm{BaFe}_{12} \mathrm{O}_{19}$ masih terbatas, khususnya berkaitan dengan sifat magnetik dan struktur mikronya. Oleh karena itu efek penambahan aditif FeMo pada serbuk $\mathrm{BaFe}_{12} \mathrm{O}_{19}$ berkontribusi merubah sifat magnetik (soft magnetik) sehingga dapat digunakan untuk tujuan tertentu. Nilai koersivitas digunakan untuk membedakan antara hard atau soft magnet, artinya semakin besar gaya koersivitasnya maka semakin tinggi sifat kemagnetannya. Sebaliknya semakin kecil nilai koersivitasnya maka semakin mudah untuk menghilangkan sifat kemagnetannya.Hal inilah yang merupakan tujuan penelitian dalam menambahkan aditif FeMo pada serbuk $\mathrm{BaFe}_{12} \mathrm{O}_{19}$ dan kondisi suhu kalsinasi.

Suhu kalsinasi yang digunakan dalam penelitian ini adalah 1000 , dan $1200^{\circ} \mathrm{C}$ selama 2 jam berdasarkan hasil penelitian sebelumnya [10]. Bahan serbuk magnet $\mathrm{BaFe}_{12} \mathrm{O}_{19}$ yang digunakan adalah merupakan produk komersil (buatan China). Pokok bahasan dalam penelitian ini adalah mengamati pengaruh penambahan aditif FeMo pada serbuk $\mathrm{BaFe}_{12} \mathrm{O}_{19}$ ditinjau dari sifat fisis dan magnetiknya.

\section{METODE PERCOBAAN}

Pada tahap awal dilakukan penggerusan bahan baku berupa serbuk Barium heksaferit $\left(\mathrm{BaFe}_{12} \mathrm{O}_{19}\right)$ dengn menggunakan Planetary Ball Mill (PBM) selama 24 jam. Secara terpisah aditif FeMo digerus secara wet milling menggunakan High Energy Milling (HEM) dengan media toluen selama 1 jam. Kemudian, serbuk FeMo dikeringkan dengan oven pada suhu $100^{\circ} \mathrm{C}$ selama 24 jam untuk menghilangkan kandungan toluen. Selanjutnya serbuk $\mathrm{BaFe}_{12} \mathrm{O}_{19}$ dan aditif FeMo (1, 5 dan 9\% wt) dicampurkan dengan menggunakan HEMselama 15 menit. Campuran serbuk $\mathrm{BaFe}_{12} \mathrm{O}_{19}$ dan aditif FeMo diukur nilai densitasnya dengan menggunakan piknometer. Kemudian serbuk dikalsinasi pada suhu 1000 , dan $1200^{\circ} \mathrm{C}$ selama 2 jam dengan heating rate $10^{\circ} \mathrm{C} /$ menit. Proses kalsinasi tersebut dilakukan dengan menggunakan alat Thermolyne Furnace High Temperature.

Pengujian true density dari campuran serbuk $\mathrm{BaFe}_{12} \mathrm{O}_{19}$ dan aditif FeMo dilakukan dengan piknometer dan menggunakan toluen sebagai medianya. Sifat magnet meliputi magnetisasis saturasi $\left(\mathrm{M}_{\mathrm{s}}\right)$, magnetik remanensi $\left(\mathrm{M}_{\mathrm{r}}\right)$, koersivity $\left(\mathrm{jH}_{\mathrm{c}}\right)$ dan energi produk maksimum $\left(\mathrm{BH}_{\max }\right)$ diukur dengan menggunakan Vibrating Sample Magnetometer (VSM). Selanjutnya analisa fasa dan struktur kristal dari campuran serbuk $\mathrm{BaFe}_{12} \mathrm{O}_{19}$ dan aditif FeMo sebelum dan setelah kalsinasi diamati dengan menggunakan X-Ray Diffraction $(X R D)$.

\section{HASIL DAN PEMBAHASAN}

Dari Gambar 1, dapat diketahui bahwa hasil pengukuran densitas menunjukan pengaruh penambahan zat aditif FeMo menaikkan nilai densitas dari magnet permanen barium heksaferit mulai $3,22-4.61 \mathrm{~g} / \mathrm{cm}^{3}$. Hal ini disebabkan nilai densitas FeMo yang lebih besar 


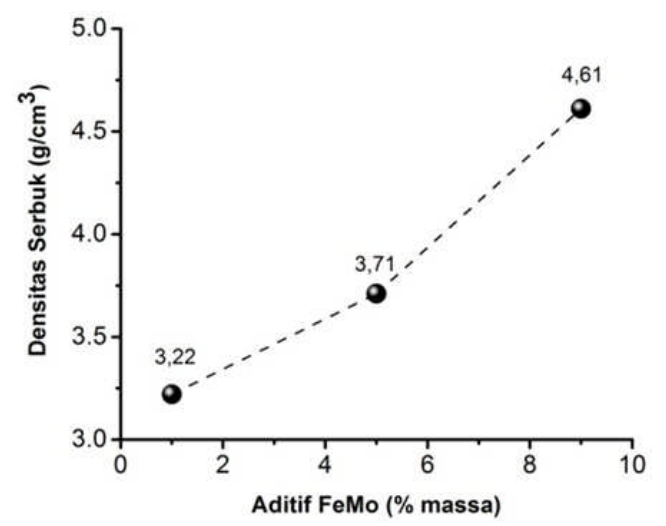

Gambar 1. Pengaruh penambahan aditif FeMo pada nilai densitasserbuk.

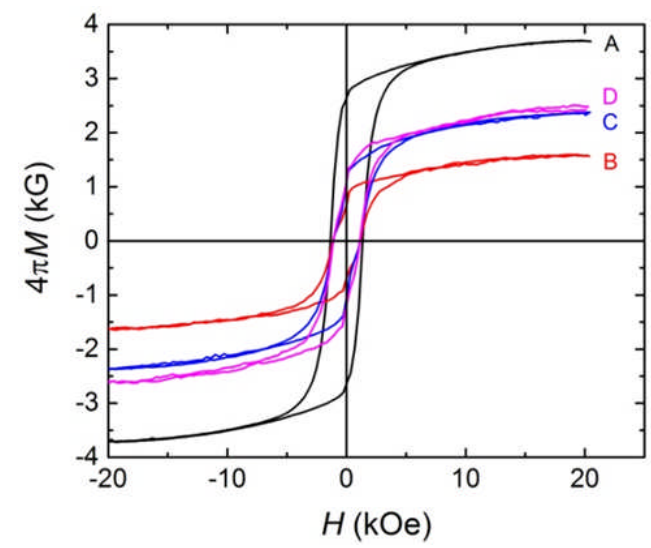

Gambar 2. Kurva histeresis dari hasil analisis sifat magnet pada (A) serbuk $\mathrm{BaFe}_{12} \mathrm{O}_{19}$ penambahan (B) 1, (C) 5 dan (D) $9 \%$ wt FeMo terhadap $\mathrm{BaFe}_{12} \mathrm{O}_{19}$

dibandingkan nilai densitas barium heksaferit. Pengaruh aditif FeMo pada magnet barium heksaferit terlihat pada Gambar 2. Penambahan aditif secara keseluruhan menurunkan sifat magnetik dari barium heksaferit. Hal ini disebabkan dari sifat soft magnetik dari FeMo [11]. Namun kenaikkan \%wt dari aditif FeMo mengakibatkan kenaikan nilai remenensi, saturasi dan $\mathrm{BH}_{\text {max }}$ dari magnet barium heksaferit. Ini pengaruh perbedaan nilai densitas dari barium heksaferit + aditif FeMo yang semakin meningkat.

Pada Tabel 1, terlihat bahwa efek penambahan aditif sebanyak 5\% wt FeMo pada serbuk barium heksaferit sebelum dikalsinasi, menghasilkan nilai koersivitas terkecil 1,03 kOe, dengan nilai remanensi 1.08 $\mathrm{kG}$, saturasi $2,37 \mathrm{kG}$ serta $\mathrm{BH}_{\text {max }} 0.140 \mathrm{MGOe}$. Berdasarkan

Tabel 1. Hasil analisis Vibrating Sample Magnetometer (VSM) pada penambahan aditif FeMo (1, 5, dan 9\%wt) pada serbuk $\mathrm{BaFe}_{12} \mathrm{O}_{19}$.

\begin{tabular}{ccccc}
\hline $\begin{array}{c}\text { Aditif FeMo } \\
(\% \mathrm{wt})\end{array}$ & $\begin{array}{c}4 \pi M_{\mathrm{s}} \\
(\mathrm{kG})\end{array}$ & $\begin{array}{c}4 \pi M_{\mathrm{r}} \\
(\mathrm{kG})\end{array}$ & $\begin{array}{c}\mathrm{j} H_{\mathrm{c}} \\
(\mathrm{kOe})\end{array}$ & $\begin{array}{c}B H_{\max } \\
(\mathrm{MGOe})\end{array}$ \\
\hline 0 & 3,70 & 2,64 & 1,34 & 0,914 \\
1 & 1,59 & 0,66 & 1,15 & 0,065 \\
5 & 2,37 & 1,08 & 1,03 & 0,140 \\
9 & 2,49 & 1,13 & 1,11 & 0,152 \\
\hline
\end{tabular}

data tersebut penambahan aditif FeMo pada magnet barium heksaferit menghasilkan material magnetik yang dikategorikan sebagai soft magnetik dengan nilai saturasi yang cukup baik. Dengan demikian ditetapkan kondisi untuk proses selanjutnyaadalah pada penambahan aditifsebanyak 5\% wt FeMo pada serbuk $\mathrm{BaFe}_{12} \mathrm{O}_{19}$.

Jika dibandingkan dengan sifat magnet untuk sampel serbuk $\mathrm{BaFe}_{12} \mathrm{O}_{19}$ (komersil) tanpa penambahan aditif, nilai tersebut relatif lebih rendah. Hal ini dikarenakan pengaruh substitusi ion logam (misal: $\mathrm{Zn}$, $\mathrm{Fe}$ ) terhadap $\mathrm{BaFe}_{12} \mathrm{O}_{19}$ [12]. Hasil penelitian dari literatur menunjukkan bahwa penambahan ion logam dapat mereduksi sifat magnet sampel sebagai akibat dari terganggunya arah momen magnet dengan munculnya ion substitusi atau ion Fe sehingga domain magnet menjadi random [13].

Nilai $\mathrm{BH}_{\max }$ merupakan suatu pengukuran dari energi potensial magnetik yang didapatkan dari luasan daerah pada kuadran kedua dari kurva histerisis sehingga diperoleh kurva (BH) yaitu perkalian B dan H. Daerah kuadran kedua merupakan tempat kedudukan titik-titik luasan di bawah kurva demagnetisasi sehingga energi produk dipengaruhi oleh nilai remanensi dan koersivitas. Dari Gambar 3 dapat dilihat bahwa energi produk maksimum $\left(\mathrm{BH}_{\max }\right)$ tidak hanya bergantung pada nilai $\mathrm{H}_{\mathrm{c}}$ dan $B_{r}$, tetapi juga bergantung pada bentuk kurva demagnetisasi [14].

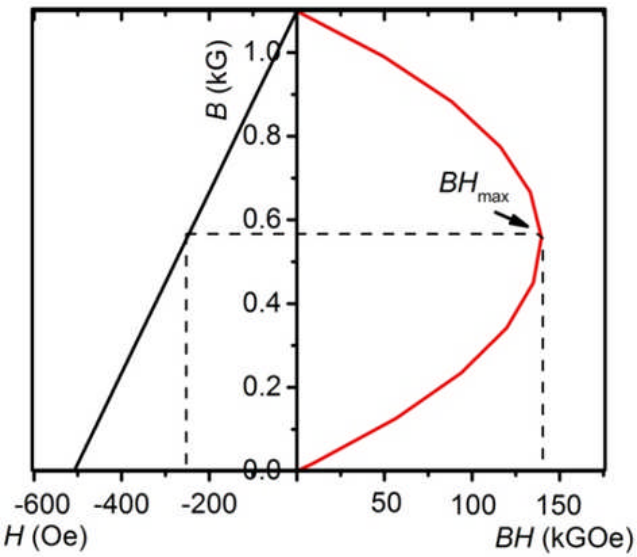

Gambar 3. Kurva demagnetisasi pada kuadran kedua dari serbuk $\mathrm{BaFe}_{12} \mathrm{O}_{19}$ dengan penambahan $5 \%$ wt FeMo

Sampel dengan aditif 5\%wt FeMo pada serbuk $\mathrm{BaFe}_{12} \mathrm{O}_{19}$ sebelum dan setelah kalsinasi pada suhu 1000, dan $1200^{\circ} \mathrm{C}$ selama 2 jam dikarakterisasi sifat magnetnya dengan menggunakan VSM diperlihatkan pada Gambar 4 dan Tabel 2.

Dari Gambar 4 dan Tabel 2, menunjukkan bahwa nilai koersivitas terendah diperoleh pada penambahan aditif 5\%wt FeMo terhadap serbuk $\mathrm{BaFe}_{12} \mathrm{O}_{19}$ setelah kalsinasi $1000^{\circ} \mathrm{C}$ selama 2 jam, yaitu sebesar $0,45 \mathrm{kOe}$. Hal ini menunjukkan bahwa efek suhu kalsinasi juga memegang peranan penting dalam membentuk soft magnetik. Sedangkan 


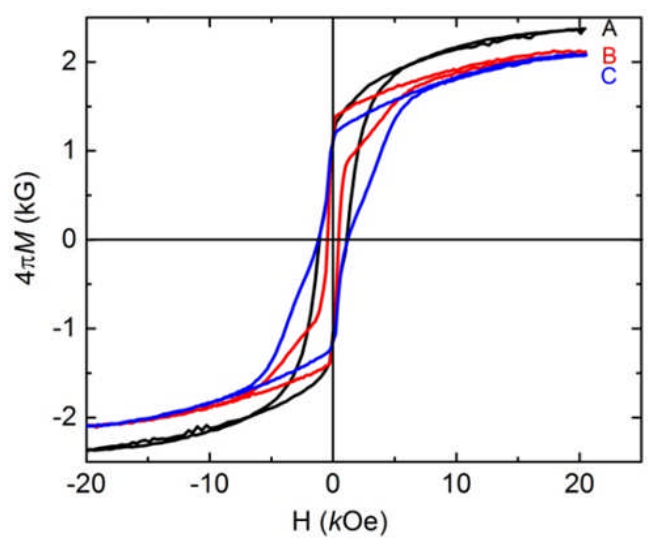

Gambar 4. Kurva histeresis sampel dengan aditif 5\%wt FeMo pada (A) serbuk $\mathrm{BaFe}_{12} \mathrm{O}_{19}$ sebelum dan setelah kalsinasi pada temperatur (B) 1000 , dan (C) $1200^{\circ} \mathrm{C}$ selama 2 jam

Tabel 2. Sifat magnetik padapenambahan aditif 5\%wt FeMo terhadap serbuk $\mathrm{BaFe}_{12} \mathrm{O}_{19}$ sebelum dan setelah kalsinasi 1000 , dan $1200^{\circ} \mathrm{C}$ selama 2 jam

\begin{tabular}{ccccc}
\hline $\begin{array}{c}\text { Kode } \\
\text { sampel }\end{array}$ & $\begin{array}{c}4 \pi M_{\mathrm{s}} \\
(\mathrm{kG})\end{array}$ & $\begin{array}{c}4 \pi M_{\mathrm{r}} \\
(\mathrm{kG})\end{array}$ & $\begin{array}{c}\mathrm{j} H_{\mathrm{c}} \\
(\mathrm{kOe})\end{array}$ & $\begin{array}{c}B H_{\max } \\
(\mathrm{MGOe})\end{array}$ \\
\hline Sebelum kalsinasi & 2,37 & 1,08 & 1,03 & 0,140 \\
$1000^{\circ} \mathrm{C}$ & 2,12 & 1,15 & 0,45 & 0,145 \\
$1200^{\circ} \mathrm{C}$ & 2,08 & 1,10 & 1,18 & 0,165 \\
\hline
\end{tabular}

meningkatnya suhu kalsinasi menjadi $1200{ }^{\circ} \mathrm{C}$ (2 jam) nilai koersivitas meningkat menjadi $1,18 \mathrm{kOe}$.

Hasil karakterisasi tersebut menunjukkan bahwa serbuk dengan suhu kalsinasi $1000^{\circ} \mathrm{C}$ memiliki sifat magnet yang paling baik. Sedangkan pada suhu $1200^{\circ} \mathrm{C}$ menghasilkan kandungan hematite $\left(\mathrm{Fe}_{2} \mathrm{O}_{3}\right)$, sebagai impurity sekunder, yang semakin banyak dan menyebabkan penurunan pada nilai remanensi dan saturasi serbuk [15].

Pada Gambar 5 ditunjukkan kurva $\mathrm{BH}_{\max }$ dari serbuk $\mathrm{BaFe}_{12} \mathrm{O}_{19}$ dengan penambahan 5\%wt FeMo yang dikalsinasi pada suhu $1000{ }^{\circ} \mathrm{C}(2 \mathrm{jam})$.

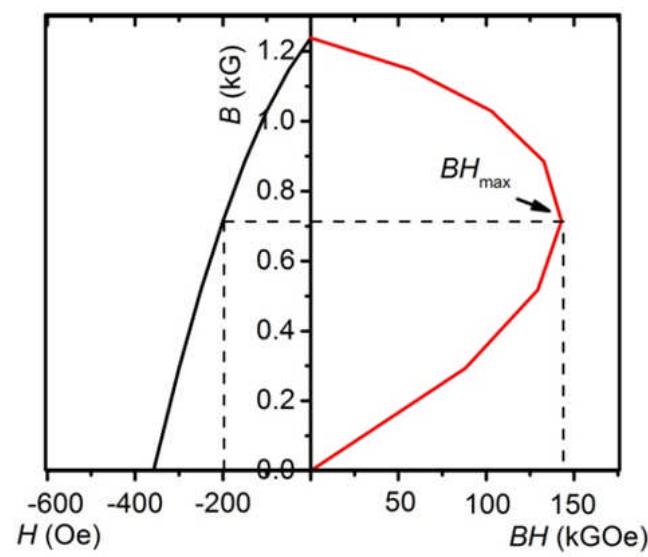

Gambar 5. Kurva demagnetisasi pada kuadran kedua dari serbuk $\mathrm{BaFe}_{12} \mathrm{O}_{19}$ dengan penambahan $5 \%$ wt FeMo yang dikalsinasi pada temperatur $1000^{\circ} \mathrm{C}$ selama 2 jam
Penurunan nilai remanensi dan koersivitas pada serbuk sesuai dengan hasil analisis XRD yang ditunjukkan pada Gambar 6.

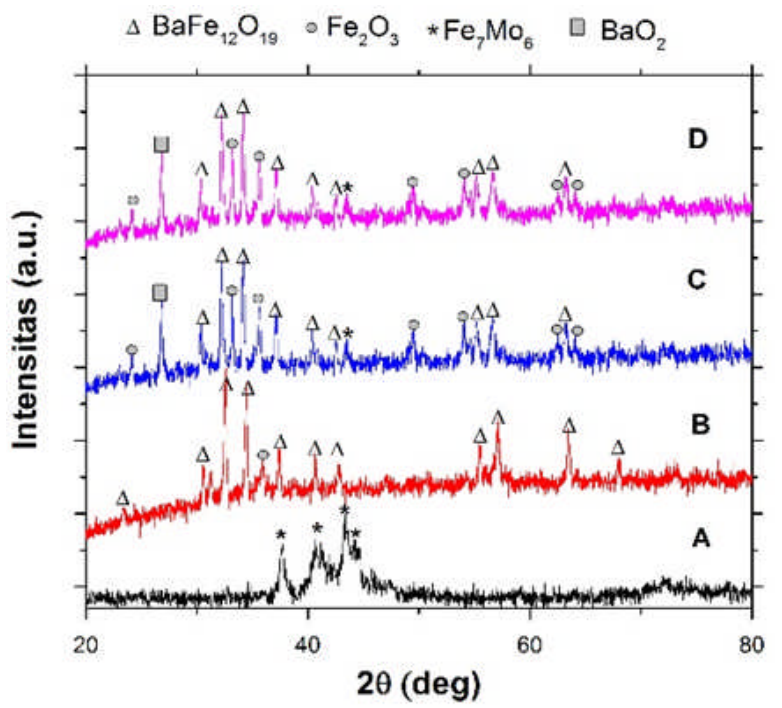

Gambar 6. Hasil analisis XRD (A) serbuk FeMo (B) serbuk $\mathrm{BaFe} 12 \mathrm{O} 19$, (C) serbuk $\mathrm{BaFe}_{12} \mathrm{O}_{19}$ dengan penambahan $5 \%$ wt FeMo yang dikalsinasi pada temperatur $1000^{\circ} \mathrm{C}$, (D) serbuk $\mathrm{BaFe}_{12} \mathrm{O}_{19}$ dengan penambahan 5\%wt FeMo yang dikalsinasi pada temperatur $1200^{\circ} \mathrm{C}$ selama 2 jam

Dari hasil analisis $X R D$ yang menggunakan sofwareMatch! menunjukkan bahwa serbuk (B) tanpa aditif FeMo dan proses kalsinasi menghasilkan 81,9\% fasa mayor barium heksaferit $\left(\mathrm{BaFe}_{12} \mathrm{O}_{19}\right)$ dengan parameter kisi $\mathrm{a}=\mathrm{b}=5,865 \AA$; $\mathrm{c}=23,099 \AA$ dan $18,1 \%$ fasa minor hematit $\left(\mathrm{Fe}_{2} \mathrm{O}_{3}\right)$. Serbuk (C) menghasilkan $40,13 \%$ fasa barium heksaferit $\left(\mathrm{BaFe}_{12} \mathrm{O}_{19}\right)$ dengan parameter kisi $\mathrm{a}=\mathrm{b}=5,893 \AA, \mathrm{c}=23,194 \AA$, 37,7 \% fasa hematit $\left(\mathrm{Fe}_{2} \mathrm{O}_{3}\right), 10,7 \%$ fasa barium oxide $(\mathrm{BaO})$ dan 11,47 $\%$ fasa $\mathrm{Fe}_{7} \mathrm{Mo}_{6}$. Serbuk (D)menghasilkan $40,9 \%$ fasa barium heksaferit $\left(\mathrm{BaFe}_{12} \mathrm{O}_{19}\right)$ dengan parameter kisi $\mathrm{a}=\mathrm{b}=5,892 \AA, \mathrm{c}=23,183 \AA, 36,8 \%$ fasa hematit $\left(\mathrm{Fe}_{2} \mathrm{O}_{3}\right), 10,6 \%$ fasa barium oxide $(\mathrm{BaO})$ dan $11,7 \%$ fasa $\mathrm{Fe}_{7} \mathrm{Mo}_{6}$.

Data hasil analisis $X R D$ ini membuktikan bahwa pengaruh suhu kalsinasi mampu menurunkan sifat kemagnetan dari magnet permanen barium heksaferit yang diakibatkan adanya proses perubahan fasa dengan terbentuknya fasa baru pada proses kalsinasi.

Dari hasil analisis dapat disimpulkan bahwa penambahan aditif FeMo dan proses kalsinasi mampu menurunkan sifat magnetik dari magnet permanen barium heksaferit dari hard magnetik menuju soft magnetik, sehingga dapat diaplikasikan sebagai sensor magnetik pada sistem keamanan [16-17].

Sifat magnet yang diutamakan pada penelitian ini adalah pada nilai koersivitas yang rendah sehingga pada proses magnetisasi dapat berlangsung relatif lebih cepat. Selain itu besarnya nilai induksi remanen $\left(\mathrm{B}_{\mathrm{r}}\right)$ dari bahan juga mempengaruhi proses demagnesisasi suatu bahan sehingga medan magnet luar menjadi nol, dan 
sering disebut magnetisasi sisa. Keberhasilan penelitian ini sangat tergantung pada sifat magnet dan berkorelasi dengan struktur mikro setelah sampel mengalami proses kalsinasi.

\section{KESIMPULAN}

Sintesis serbuk $\mathrm{BaFe}_{12} \mathrm{O}_{19}$ dengan penambahan aditif FeMo telah berhasil dilakukan melalui metode Mechanical Alloying. Penambahan 5\%wt FeMo merupakan penambahan aditif optimum dengan nilai densitas $3,71 \mathrm{~g} / \mathrm{cm}^{3}$ sebelum proses kalsinasi dan memiliki sifat magnet paling baik setelah proses kalsinasi pada suhu $1000^{\circ} \mathrm{C}$ dengan nilai saturasi $2.12 \mathrm{kG}$, remanensi $1,15 \mathrm{kG}$, koersivitas $0,45 \mathrm{kOe}$ dan $\mathrm{BH}_{\max }$ 0,145 MGOe. Hasil analisis $X R D$ menunjukkan bahwa Serbuk $\mathrm{BaFe}_{12} \mathrm{O}_{19}$ dengan penambahan aditif 5\%wt FeMo yang sudah dikalsinasi pada suhu $1000^{\circ} \mathrm{C}$ memiliki fasa dominan $40,13 \%$ barium heksaferit $\left(\mathrm{BaFe}_{12} \mathrm{O}_{19}\right)$, fasa minor $37,7 \%$ hematite $\left(\mathrm{Fe}_{2} \mathrm{O}_{3}\right), 11,47$ FeMo dan $10,7 \%$ barium oxide $\left(\mathrm{BaO}_{2}\right)$. Hasil sintesis dan karakterisasi serbuk magnet menunjukkan bahwa serbuk magnet yang telah dibuat menuju struktur material soft magnetik yang dapat diaplikasikan sebagai sensor magnetik dan sistem on/off pada alat telekomunikasi.

\section{UCAPAN TERIMAKASIH}

Penulis mengucapkan terima kasih kepada program DIPA Pusat Penelitian Fisika-LIPI, 2016 atas pembiayaan dalam penelitian ini.

\section{DAFTAR ACUAN}

[1]. R. Doni, A. Manaf, dan P. Sardjono. "Physical Characteristics and Magnetic Properties of Barium Hexaferrites $\left(\mathrm{BaFe}_{12} \mathrm{O}_{19}\right)$ Derived from Mechanical Alloying. "International Journal of Basic \& Applied Sciences IJBAS-IJENS, vol.13, no. 4, 2013.

[2]. R. C. Pullar, M. Saeli, R. M. Novais, J. A. Amaral, and J. A. Labrincha. "Valorisation of Industrial Iron Oxide Waste to Produce Magnetic Barium Hexaferrite. "Journal Chemistry Select,vol.4, pp. 819-825, 2016.

[3]. D. S. Winataputra, E. Sukirman. S. Wardiyati dan S. Purnama. "Karakterisasi $\mathrm{BaFe}_{12} \mathrm{O}_{19}$ Koersivitas Tinggi Hasil Sintesis Dengan Metode Kopresipitas Kimia." Jurnal Sains Dan Teknologi Nuklir Indonesia. vol.14, no.2, 2013.

[4]. I. Stefan, A. Olei, and C. Nicolicescu. "Research on Mechanical Alloying Effects on Magnetic Propertiesof Barium Ferrite Type M.” in The 4th International Conference, Advanced Composite Materials Engineering, Comat 2012.

[5]. Y. H. Huang, J. Z. Yang, Y. G. Liu, M. H. Fang, J. T. Huang, H. R. Sun and S. F. Huang. "Novel SialonBased Ceramics Toughened by Ferro-Molybdenum
Alloy." J.Am. Ceram. Soc., vol. 95, no. 3, pp. 859-861. 2012.

[6]. M. Marinov, G. Mushec, P. Petrov, R. Paunova and R. Aleksandrova. "Production Efficiency of A FerroMolibdenum Alloy."Journal of Chemical Technology And Metallurgy, vol.49, no. 1, pp. 45-48. 2014.

[7]. K. Rosyidah, dan M. Zainuri."Sintesis dan Karakterisasi Struktur dan Sifat Magnet Komposit Barium M-Heksaferit/Polianilin Berstruktur Core-Shell Berbasis Pasir Besi Alam.”Jurnal Teknik Pomits, vol. 1, no. 1, 2013.

[8]. A. Doyan, I. Halik, dan Susilawati. "Pengaruh Variasi Temperatur Kalsinasi Terhadap Barium MHeksaferit Didoping Zn Menggunakan Fourier Transform Infra-Red, J. Pijar Mipa, vol. X no.1, pp. 7-15, 2015

[9]. W. Gao, Z. Li and N. Sammes. "An Introduction To Electronic Materials For Engineers." in $2^{\text {th }}$ Edition. World Scientific, London, 2011.

[10]. M. M.S Sanad and M.M. Rashad. "Cost-effective Integrated Strategy for The Fabrication of HardMagnet Barium Hexaferrite Powders From LowGrade Barite One." International Journal of Minerals, Metallurgy and Materials, vol. 23, no.9, pp. 991, 2016.

[11]. B. Slusarek, and K. Zakrzewski. "Magnetic Properties of Permanent Magnets For Magnetic Sensors Working In Wide Range Of Temperature, Przegląd Elektrotechniczny (Electrical Review)." 2012.

[12]. L. Li and Beilun. "Acousto-Magnetic Anti-Theft Label with a High Coercivity Bias and Method of Manufacture.” U.S. Patent, No. US 8746580 B2, Jun. 10, 2014.

[13]. M. Fujiyoshi and S. Yokoyama. "Semi-Hard Magnetic Material and Theft-Prevention Magnetic Sensor Using Same and Method of Manufacturing Semi-Hard Magnetic Materials." U.S. Patent, No. US 9500720 B2, Nov. 22, 2016.

[14]. A. M. Soehada, K. Sebayang, T. Sudiro, C. Kurniawan, dan P. Sebayang. "Effect of Mn-Ti Ions Doping and Sintering Temperature on Properties of Barium Hexaferrite)." Jurnal Sains Materi Indonesia, vol. 15, no. 4, pp. 192-195, 2014.

[15]. D. Ambarwanti, E. Handoko, dan M. A. Marpaung. "Struktur dan Sifat Kemagnetan Material Magnet $\mathrm{BaFe}_{12} \mathrm{Mn}_{\mathrm{x}} \mathrm{Zn}_{\mathrm{x}} \mathrm{O}_{19}$ yang Disiapkan dengan Metode Ultrasonic Mixing." Prosiding Pertemuan Ilmiah XXVIII HFI Jateng \& DIY, pp. 312-314.

[16]. Sulistyo, I. Marhaendrajaya dan Priyono. "Sintesis dan Karakterisasi Material Magnetik Barium Hexaferrite Tersubstitusi Menggunakan Teori Solgel Untuk Aplikasi Serapan Gelombang Mikro Pada Frekuensi X-Band.” Berkala Fisika, vol. 15, no. 2, pp. 63 - 68, 2012. 
[17] Priyono dan W.G. Prasongko. "Pembuatan Material Komposit $\mathrm{BaFe}_{9} \mathrm{Mn}_{0.75} \mathrm{Co}_{0.75} \mathrm{Ti}_{1.5} \mathrm{O}_{19} /$ Elastomer untuk Aplikasi Penyerap Gelombang Elektromagnetik." Jurnal Sains dan Matematika, vol. 21, no. 1, pp. 15-19, 2013.
[18] W. Wong-Ng, H. F. Mc Murdie, C. R. Hubbard, and A. D. Mighell. "JCPDS-ICDD Research Associateship (Cooperative Program with NBS/ NIST)." Journal of Research of The National Institute of Standards and Technology, vol. 106, no 6,pp. 1013-1028, 2001. 